\title{
Growth Analysis Of Three Aquatic Commodities Cultivated With Polyculture Systems at Different Densities
}

\author{
Author \\ Gawest Bagus Permana (Orcid ID. 0000-0002-9459-0405), \\ Andi Rahmad Rahim (Orcid ID. 0000-0001-5514-6291), \\ Aminin (Orcid ID. 0000-0002-0324-0734)

\begin{abstract}
Correspondence
Students of Aquaculture Study Program, Faculty of Agriculture, University of Muhammadiyah Gresik Lecturer of Aquaculture Study Program, Faculty of Agriculture, University of Muhammadiyah Gresik gawestbagusp@gmail.com, andirahmad@umg.ac.id
\end{abstract}

\begin{abstract}
Vanamei shrimp and milkfish (Chanos Chanos) are now being cultivated in ponds using a polyculture system maintained simultaneously in one container. The development of cultivation technology shows that seaweed can be produced along with shrimp and milkfish in ponds. The addition of seaweed is expected to increase production and improve the environmental conditions of cultivation. This polyculture cultivation system can increase the efficiency of land use can also increase the productivity of ponds. This research was conducted in the pond of Glagah Lamongan village for 42 days. This study used milkfish, shrimp vaname and seaweed Gracilaria verrucosa. The research method uses the Complete Randomized Design (RAL) method with three treatments and three repeats. It gets nine experimental units; the data in the analysis using ANOVA is conducted tukey further tests. Treatment A (density of milkfish and shrimp ten tails $/ \mathrm{m}^{2}$, seaweed $250 \mathrm{~g} / \mathrm{m}^{2}$ ), treatment B (density of milkfish and shrimp $20 \mathrm{tails} / \mathrm{m}^{2}$, seaweed $500 \mathrm{~g} / \mathrm{m}^{2}$ ), treatment $\mathrm{C}$ (density of milkfish and shrimp 30 tails $/ \mathrm{m} 2$, seaweed $1000 \mathrm{~g} / \mathrm{m}^{2}$ ). Variables taken are the Absolute Length of milkfish, shrimp vaname and seaweed. The results obtained the total length of milkfish, shrimp vaname and seaweed highest in treatment A (7.67 \pm $0.54^{\mathrm{a}}$ ). Water quality during maintenance, temperature ranges from $29.2-32.8^{\circ} \mathrm{C}$; D.O. 1.1$3.4 \mathrm{mg} / \mathrm{l}$; Salinity $1-3 \mathrm{ppt}$; brightness range $24-50 \mathrm{~cm}$ and ground redox obtain a range value of 42-(-328)mV.
\end{abstract}

Keywords: Polyculture, Absolute length, Water quality, Soil redox.

Received: 17 May 2021. Accepted: 23 June 2021

\section{Introduction}

Vanamei shrimp and milkfish (Chanos Chanos) are currently being cultivated in ponds using a polyculture system maintained simultaneously in one container. Still, it is not yet known how many combinations or densities are suitable to obtain optimal growth. The development of cultivation technology shows that seaweed can be cultivated along with shrimp and milkfish in ponds. The product of seaweed cultivation in polyculture with milkfish and shrimp is intended to increase shrimp and seaweed production and more effectiveness to the use of ponds to improve the quality of the cultivation environment (Hendrajat et al., 2018).

Lamongan Regency is one of the largest vaname shrimp producers in East Java. Together with milkfish, vaname shrimp is a major commodity in the region. In 2010, a name shrimp production reached 1,911 tons 
or $52.99 \%$ of the total output from aquaculture in Lamongan Regency. The productivity of fish and shrimp depends on good environmental conditions for fish and shrimp and natural feed.

This study aims to determine the optimal density level for the growth of milkfish, shrimp vaname and seaweed cultivated polyculture, and water and soil quality.

\section{Methods}

The research method uses a complete randomized design (RAL) with three treatments and three repeats so that there are nine experimental units. Treatment A (density of milkfish and shrimp ten tails $/ \mathrm{m}^{2}$, seaweed $250 \mathrm{~g} / \mathrm{m}^{2}$ ); treatment B (density of milkfish and shrimp 20 tails $/ \mathrm{m}^{2}$, seaweed $500 \mathrm{~g} / \mathrm{m}^{2}$ ); treatment $\mathrm{C}$ (density of milkfish and shrimp 30 tails $/ \mathrm{m}^{2}$, seaweed $1000 \mathrm{~g} / \mathrm{m}^{2}$ ). This research was conducted in a pond with a $1 \times 1 \times 1 \mathrm{~m}$ tarpaulin pond in Glagah Lamongan Regency for 42 days of maintenance. The data obtained are absolute long growth data, water quality (temperature, Salinity, D.O., pH, brightness) and soil redox. The data were analyzed using analysis of variance (ANOVA) using IBM SPSS Statistic 20 application and continued using Tukey test with $95 \%$ confidence level $(\mathrm{p}<0.05)$.

\begin{tabular}{|c|c|c|}
\hline B3 & A2 & C1 \\
\hline B2 & A1 & C2 \\
\hline B1 & C3 & A3 \\
\hline
\end{tabular}

Figure 1. The layout of experimental unit placement on research

Description :

A, B and C : density treatment;

1,2 and 3 : replay

\section{Results and Discussions}

Table 1. Growth of milkfish, shrimp, and seaweed during maintenance

\begin{tabular}{|c|c|}
\hline \multicolumn{1}{|c|}{ Treatment } & $\begin{array}{c}\text { Total length }(\overline{\boldsymbol{X}} \pm \text { S.D. }) \\
(\mathbf{c m})\end{array}$ \\
\hline $\begin{array}{l}\text { A ( Milkfish 10 tails, Shrimp } \\
\text { 10 tails, and Seaweed 250 gr) }\end{array}$ & $7,67 \pm 0,54^{\mathrm{a}}$ \\
\hline
\end{tabular}

\begin{tabular}{|l|c|}
\hline $\mathrm{m}^{2}$ & \\
\hline B ( Milkfish 20 tails, Shrimp & $6,10 \pm 0,70^{\mathrm{b}}$ \\
20 tails, and Seaweed 500 gr) & \\
$\mathrm{m}^{2}$ & \\
\hline C ( Milkfish 30 tails, Shrimp & $4,88 \pm 0,14^{\mathrm{b}}$ \\
30 tails, and Seaweed 1000 gr) & \\
$\mathrm{m}^{2}$ & \\
\hline
\end{tabular}

Description :*: Different numbers show an actual different growth average at $95 \%$ confidence lapse.

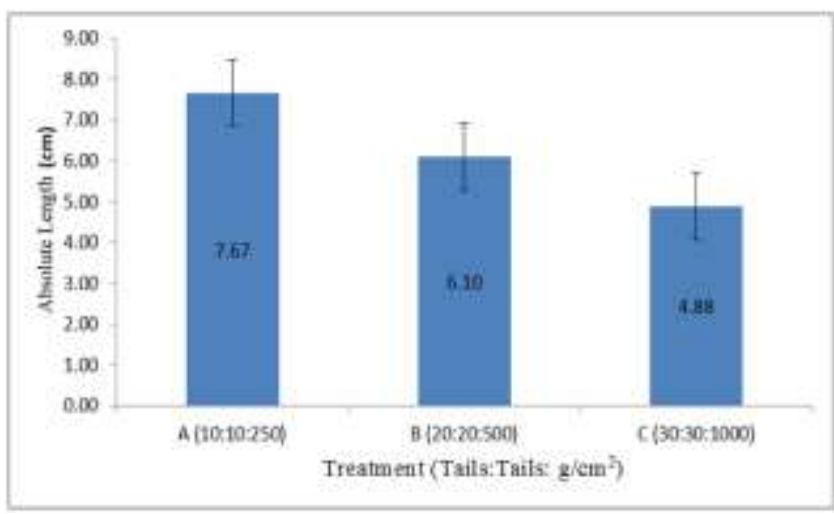

Figure 2. Absolute length of shrimp, milkfish and seaweed during maintenance

The results showed that the difference in density of milkfish, shrimp vaname and seaweed Gracilaria verrucosa showed a noticeable difference $(\mathrm{P}<0.05)$ to the growth of milkfish, shrimp vaname and seaweed Gracilaria verrucosa. The highest absolute length growth was obtained at treatment $\mathrm{A}$ $7.67 \pm 0.54 \mathrm{~cm}$.

\section{Absolute Length}

The results showed that the absolute long growth of milkfish, shrimp vaname and seaweed Gracilaria verrucosa cultivated by polyculture method for 42 days obtained a range between $4.88 \mathrm{~cm}-7.67 \mathrm{~cm}$ (Figure 5). The three treatments received the best value, namely in the treatment of A (density of milkfish and shrimp ten tails $/ \mathrm{m}^{2}$, seaweed 250 $\mathrm{g} / \mathrm{m}^{2}$ ), a matter of $7.67 \pm 0.54 \mathrm{~cm}$. Then the treatment of B (density of milkfish and shrimp 20 tails $/ \mathrm{m}^{2}$, seaweed $500 \mathrm{~g} / \mathrm{m}^{2}$ ) is $6.10 \pm 0.70 \mathrm{~cm}$, and the treatment $\mathrm{C}$ (density of milkfish and shrimp 30 tails $/ \mathrm{m}^{2}$, seaweed $1000 \mathrm{~g} / \mathrm{m}^{2}$ ) with a value of $4.88 \pm 0.14 \mathrm{~cm}$ is no 
different (in Table 4). It is suspected that the high level of dense spread that is too high in the $\mathrm{B}$ and $\mathrm{C}$ treatments causes a lack of little wiggle room so that the fish are more likely to experience stress. This proves that growth decreases as the solid spread increases. From the results of analysis of variance (ANOVA) showed that different density treatment shows a real influence on absolute long growth $(p<0.05)$, then carried out further tests using Tukey.

Further test results using Tukey showed significant results $(p<0.05)$. Treatment A (density of milkfish and shrimp ten tails $/ \mathrm{m}^{2}$, seaweed $250 \mathrm{~g} / \mathrm{m}^{2}$ ) is different from the treatment B (density of milkfish and shrimp 20 tails $/ \mathrm{m}^{2}$, seaweed $500 \mathrm{~g} / \mathrm{m}^{2}$ ) and with treatment $\mathrm{C}$ (density of milkfish and shrimp 30 tails $/ \mathrm{m}^{2}$, seaweed $\left.1000 \mathrm{~g} / \mathrm{m}^{2}\right) \quad(\mathrm{p}<0.05)$. Treatment B (density of milkfish and shrimp 20 tails $/ \mathrm{m}^{2}$, seaweed $500 \mathrm{~g} / \mathrm{m}^{2}$ ) differs noticeably with treatment A (density of milkfish and shrimp ten tails $/ \mathrm{m}^{2}$, seaweed $\left.250 \mathrm{~g} / \mathrm{m}^{2}\right)(\mathrm{p}<0.05)$. Treatment B (density of milkfish and shrimp 20 tails $/ \mathrm{m}^{2}$, seaweed $\left.500 \mathrm{~g} / \mathrm{m}^{2}\right)$ is no different from the $\mathrm{C}$ treatment (milkfish density and shrimp 30 tails $/ \mathrm{m}^{2}$, seaweed $\left.1000 \mathrm{~g} / \mathrm{m}^{2}\right) \quad(\mathrm{p}>0.05)$. Treatment $\mathrm{C}$ (density of milkfish and shrimp 30 tails $/ \mathrm{m}^{2}$, seaweed $1000 \mathrm{~g} / \mathrm{m}^{2}$ ) differs noticeably with treatment A (density of milkfish and shrimp ten tails $/ \mathrm{m}^{2}$, seaweed $\left.250 \mathrm{~g} / \mathrm{m}^{2}\right)(\mathrm{p}<0.05)$ but no different from the $\mathrm{B}$ treatment (milkfish density and shrimp 20 tails $/ \mathrm{m}^{2}$, seaweed $\left.500 \mathrm{~g} / \mathrm{m}^{2}\right)(\mathrm{p}>0.05)$. In treatment A obtained the highest value because competition in the scramble of feed is not too difficult but can be balanced because the size of the pond corresponds to the dense spread of fish. Vaname shrimp and milkfish can take advantage of feed and more space so that sunlight can enter the cultivation and seaweed can take photosynthesis process, and existing nutrients can be utilized for growth (Putri and Susilowati, 2013).

Treatment B and C lead to favourable treatment in the utilization of aquatic space. The addition of seaweed volume up to 2 times in the $\mathrm{C}$ treatment with seaweed 1000gram can support 30 milkfish and 30 shrimps in one room. The growth rate is the same as the B treatment, while treatment $\mathrm{B}$ with the addition of 500grams of seaweed can only support 20 milkfish and 20 shrimp in the aquaculture pond. It can provide benefits to milkfish and shrimp as a growth element to increase the room's capacity. The utilization of ecological niches in cultured polycultures of milkfish, shrimp and seaweed can add value to cultivated commodities (Reksono et al., 2012). Seaweed (Gracilaria verrucosa) will produce oxygen as well as a shelter for milkfish and shrimp from the heat of the sun. Shrimp droppings and milkfish can be utilized by seaweed as nutrients and fertilizers; the activity of milkfish that move up to the bottom of the water in search of feed can help control the growth of seaweed (Gracilaria verrucosa) overgrown with algae and plankton so as not to bloom.

An important factor that causes the growth rate of seaweed is the difference in light intensity acceptable to seaweed (Putra et al., 2011). The current obtained from the movement of milkfish can carry enough nutrients and at the same time can wash the dirt attached to the seaweed thallus, which is an organism that obtains food (nutrients) through the flow of water that passes through it. The increasing increase of thallus will result in competition between thallus in one clump to get sunlight, and absorption of nutrients is more excellent. This resulted in increased thallus stress due to the greater competition between thallus in one family (Putra et al., 2011).

\section{Water Quality}

Table 2. Water Quality Parameter Range for 42 days of maintenance

\begin{tabular}{|c|c|c|c|c|c|c|}
\hline \multirow[b]{2}{*}{ Treatment } & \multicolumn{6}{|c|}{ Water Quality Range During Research } \\
\hline & $\begin{array}{c}\text { Temperature } \\
\text { ("C) }\end{array}$ & pH & $\underset{(\mathrm{mg} / \mathrm{l})}{\mathrm{DO}}$ & Salinity & brightness & $\begin{array}{c}\text { Ground } \\
\text { redox }\end{array}$ \\
\hline $\begin{array}{l}\text { A } \\
\text { (milkfish } \\
\text { and shrimp } \\
10 \text { tails } \mathrm{m}^{2} \text {. } \\
\text { seaweed } \\
250 \mathrm{~g}^{2} \mathrm{~m}^{2} \text { ) }\end{array}$ & $29,2-32,8$ & $\begin{array}{c}6,54 \\
7,5 \\
7,5\end{array}$ & $\begin{array}{c}1,1= \\
3,4\end{array}$ & $1-3$ & $2+50$ & $\begin{array}{l}-42-(- \\
352)\end{array}$ \\
\hline $\begin{array}{l}\text { B } \\
\text { (milk.fish } \\
\text { and shrimp } \\
20 \text { tails } \mathrm{m}^{2} \text {. } \\
\text { seaweed } \\
500 \mathrm{~g} \mathrm{~m}^{2} \text { ) }\end{array}$ & $29,4=32,4$ & $\begin{array}{l}6,88 \\
-8\end{array}$ & $\begin{array}{l}1,1-1 \\
2,2\end{array}$ & $1-2$ & $30-50$ & $\begin{array}{l}-66 \cdot(- \\
306)\end{array}$ \\
\hline $\begin{array}{l}\mathrm{C} \\
\text { (milkfish } \\
\text { and shrimp } \\
30 \text { tails } \mathrm{m}^{2} \text {, } \\
\text { beaweed } \\
1000 \mathrm{~g} / \mathrm{m}^{2} \text { ) }\end{array}$ & $30,2-32,8$ & $\begin{array}{c}6,66 \\
-8\end{array}$ & $1,1-$ & $1-2$ & $26-50$ & $\begin{array}{l}-45-(- \\
285)\end{array}$ \\
\hline
\end{tabular}


The results of water quality measurement during the 42-day study on all treatments, temperature ranged from 29.2 $32.8^{\circ} \mathrm{C}$, then $\mathrm{pH}$ levels obtained a range of values between $6.54-8$, and for the D.O. range ranged from $1.1,-3.4 \mathrm{mg} / 1$, then in the salinity range between $1-3$ ppt, for brightness values obtain a range of $24-50 \mathrm{~cm}$. Ground redox ranges from $-42-(-352)$.

\section{Temperature}

Temperature is a limiting variable that has an essential role in the life and growth of aquaculture commodities in the pond. Temperature plays a role in helping to accelerate the metabolic processes of cultivated animal organisms (Mangampa \& Burhanuddin, 2014). In this range, the temperature in all research for milkfish commodity value is already at a decent range for aquaculture organisms' life and growth, including seaweed. The optimal temperature for vanname shrimp cultivation ranges from $26-31^{\circ} \mathrm{C}$ (Arsad et al., 2017). According to Mangampa \& Burhanuddin (2014), the temperature between 27-33oC Such values is in a decent range for cultivated organisms' life and growth, including seaweed.

\section{pH}

Acidity degree $(\mathrm{pH})$ is one of the water quality parameters that can change and is influenced by many factors such as oxygen, ammonia, nitrites, organic matter. If the concentration of $\mathrm{H}$ ions increases, then the $\mathrm{pH}$ value becomes low, and vice versa. Daily fluctuations of $\mathrm{pH}<0,5$ can cause physiological disorders. The influence of $\mathrm{pH}$ can also affect the level of ammonia toxicity and natural feed such as plankton, mosses and kelekap (Mangampa \& Burhanuddin, 2014). The observations in all polyculture plot treatments observed from day 0 to day 42 obtained a $\mathrm{pH}$ range value of $6.54-8$. The value range is an appropriate value for the growth of a commodity cultivated in both milkfish, vanname shrimp and seaweed. In the mangampa \& burhanuddin research (2014), using the cultivation of milkfish polyculture, vanname shrimp, and seaweed obtained a $\mathrm{pH}$ range value between 7.5-9. The range is highly rated, especially at night and decreases in the morning but can still be tolerated by milkfish, shrimp and seaweed.

\section{Dissolved Oxygen (DO)}

In the observation of dissolved oxygen concentration (D.O.) that can be during the study obtained a value in the range of $1,1-3,4$ $\mathrm{mg} / \mathrm{l}$. This condition is a low value for the quality of polyculture cultivation D.O., but can still be tolerated by the commodities of milkfish cultivation, vanname shrimp and seaweed. This is strengthened by research (Mangampa \& Burhanuddin, 2014) in his study with the cultivation of polyculture commodities milkfish, vanname shrimp and seaweed obtained the range of Dissolved Oxygen with a range of 0,96-9,34 but can still grow. (Faisyal et al., 2016) His research received optimum growth for vanname shrimp in the D.O. range (3.25-3.05 mg/l). Therefore, the presence of seaweed as a polyculture commodity can control water quality so that the atmosphere of the pond becomes better physically, chemically and biologically that will give a good life influence on pet biota, including milkfish.

\section{Salinity}

Salinity is the level of acidity or salt content dissolved in water. From the results of obtaining salinity levels obtained a range value of 1-3 ppt. Vanname shrimp and milkfish are species with the ability to live in a wide salinity vulnerable, namely $0.50-40 \mathrm{ppt}$ or eurihaline. The wide range of this adaptation makes milkfish and vanname shrimp species very suitable to be cultivated in remote areas with the sea, though. Salinity is relatively low for seaweed growth (Gracilaria verrucosa), salinity changes are very ekstream will inhibit the growth of seaweed (Gracilaria verrucosa). (Istiqomawati \& Kusdarwati, 2010) says seaweed Gracilaria verrucosa can live and grow in widespread Salinity because it has euryhalin properties resistant to Salinity, $\mathrm{pH}$ and temperature are quite far away or have a high level of tolerance to life. 


\section{Brightness}

From the results of a 42-day study, the depth value is in the range of $24-50 \mathrm{~cm}$, which is already classified as suitable for all three commodities of milkfish, vanname shrimp and seaweed Gracillaria verrucosa. Brightness for milkfish grinding minimum $20^{\circ} \mathrm{C}$ (SNI, 2011). The lack of intensity of incoming light will cause inhibition of seaweed growth. The lack of movement of water currents causes sediment that covers the seaweed thallus to inhibit growth. Another factor that can hinder seaweed growth is the high level of density spread in each cultivation container. It will cause competition in each thallus to obtain the sun's intensity to be used in photosynthesis.

\section{Ground Redox}

Redox (Eh) is an overview of the reduction and oxidation reactions that occur in the soil. This redox parameter becomes part of the parameters that indicate the quality of pond soil (Nana and Putra, 2008). The average potential redox of vaname shrimp polyculture ponds, milkfish and seaweed on the 0th day ranges between the value $(-281 \mathrm{mV}--352 \mathrm{mV})$ with an optimal value $(>-50 \mathrm{mV})$ that is between 00-(-100), so according to Liu (1985), this value is included in the medium reduction state wherein this condition organic compounds are reduced. Soil redox value on the 0th day indicates a high reduction rate (Cyio, 2008) said that the contribution of organic matter could cause the condition of the change into the soil solution, both hydroxyl groups and other carbonyl compounds that can provide balance to the activity of $\mathrm{H}^{-}$ions that cause a decrease in the concentration of $\mathrm{H}^{+}$ions. The decline also encouraged a reduction in the number of electrons in the soil solution. The number of electrons is directly proportional to the redox potential so that the decrease in the number of electrons will automatically decrease the value of Eh. Decreased $\mathrm{Eh}$ value will cause $\mathrm{O}_{2}$ depletion up to value $(-350 \mathrm{mV})$. Ground redoks values at the end of the study ranged from $(-42 \mathrm{mV}$ to $-276 \mathrm{mV})$ to a medium reduction range value of $00=(-100)$, (optimum value $>-50 \mathrm{mV}$ ). This condition is thought to result from photosynthesis activity by phytoplankton and the respiration of aquatic organisms associated with it that contribute $\mathrm{H}^{+}$ ions and O.H.' ions. It is suspected that seaweed can improve the level of reduction in soil. Seaweed is a dissolved oxygen supplier in water obtained through photosynthesis during the day and can absorb excess nutrients and contamination materials that are toxic in the water (Murachman, 2010).

\section{Conclusions}

1. The growth of milkfish, shrimp vaname, and seaweed (Gracilaria verosca) with polyculture systems with different density treatments cultivated for 42 days exerts a real influence. The best treatment can be treatment A (density of milkfish and shrimp ten tails / $\mathrm{m} 2$, seaweed $250 \mathrm{~g} / \mathrm{m} 2$ ) of $7.67 \pm 0.54 \mathrm{~cm}$. The growth of milkfish, shrimp vaname, and seaweed (Gracilaria verosca) with polyculture systems with different density treatments cultivated for 42 days exerts a fundamental influence where the best treatment can be on treatment A (density of milkfish and shrimp ten tails $/ \mathrm{m}^{2}$, seaweed $250 \mathrm{~g} /$ $\mathrm{m}^{2}$ ) of $7.67 \pm 0.54 \mathrm{~cm}$.

2. The results of water quality analysis during the study for $\mathrm{pH}$ ranged from 6.54-8, the temperature in the range of $29.2-32.8^{\circ} \mathrm{C}$, Salinity in the field of $1-3$, to D.O. has a range of $1.1-3.4 \mathrm{mg} / 1$ and brightness in the range of $24-50 \mathrm{~cm}$.

Soil redox yields in all treatments range from $-42-(-328) \mathrm{Mv}$ 


\section{Suggestions}

1. Cultivation by polyculture method with milkfish, shrimp vaname and seaweed in obtaining optimal growth should use density treatment A (milkfish and shrimp ten tails $/ \mathrm{m}^{2}$, seaweed $250 \mathrm{gr} / \mathrm{m}^{2}$ ). If more critical in terms of land optimization/ efficiency, the treatment of $\mathrm{C}$ (density of milkfish and shrimp 30 tails $/ \mathrm{m}^{2}$, seaweed $1000 \mathrm{~g} / \mathrm{m}^{2}$ ) is a suitable treatment applied in the efforts of milkfish and shrimp.

2. It is necessary to process the soil before it is used cultivated to improve the level of soil redox to improve the fertility rate of the water.

\section{References}

Asmika H,et al.2008. Study of The Link between Oxygen Reserves And Organic Material Load In Lakustrin Zone and Transition of Ir. $\mathrm{H}$. Djuanda Reservoir. J. Lit. Perikan. Ind. Vol.14 No.1.

Cokrowati, N.; Utami, P. \& Sarifin, 2012. Solid differences spread to the growth rate and survival of post sand lobster peurulus (Panulirus homarus) in controlled tubs. Marine Journal, 5(2): 156-166, ISSN: 19079931.Effendie, M.I. 1997. Fishery Biology Method. Yayasan Pustaka Nusatama. Yogyakarta.

Andriyanto, F., A. Efani, and H. Riniwati. 2013. Analysis of production factors of shrimp enlargement business vanname Litopenaeus vannamei in Paciran District Lamongan Regency, East Java; cobb Douglass function approach. J. ECSOFiM., 1(1):82-96.

Brito, L. O.; dos Santos, I. G. S.; de Abreu, J. L.; de Araújo, M. T.; Severi, W. \& Gàlvez, A. O., 2016. Effect of adding diatoms (Navicula spp.) and rotifers (Brachionus plicatilis) on water quality and growth of the Litopenaeus vannamei postlarvae reared in a biofloc system. Aquaculture Research, 47(12): 3990-3997, ISSN: 13652109, DOI: 10.1111/are.12849.

Faisyal,dkk. 2016. The Solid Influence of Spread On The Growth and Life of Milkfish (Chanos Chanos) In Floating Net Cages In The Terabrasi Waters of Kaliwlingi Village, Brebes Regency. Journal of Aquaculture Management and Technology Volume 5, Number 1, 2016, Pages 155-161.

Ernawati and Rochmady.2017. The influence of fertilization and solid distribution on the survival rate and post-growth of shrimp larvae vaname (Litopenaues vannamei). Journal of Coastal Aquaculture and Small Islands (EISSN 2598-8298). 